\title{
Business process management and IT management: The missing integration
}

\author{
Rahimi, Fatemeh; Møller, Charles; Hvam, Lars
}

Published in:

International Journal of Information Management

Link to article, DOI:

10.1016/j.ijinfomgt.2015.10.004

Publication date:

2016

Document Version

Peer reviewed version

Link back to DTU Orbit

Citation (APA):

Rahimi, F., Møller, C., \& Hvam, L. (2016). Business process management and IT management: The missing integration. International Journal of Information Management, 36(1), 142-154.

https://doi.org/10.1016/j.ijinfomgt.2015.10.004

\section{General rights}

Copyright and moral rights for the publications made accessible in the public portal are retained by the authors and/or other copyright owners and it is a condition of accessing publications that users recognise and abide by the legal requirements associated with these rights.

- Users may download and print one copy of any publication from the public portal for the purpose of private study or research.

- You may not further distribute the material or use it for any profit-making activity or commercial gain

- You may freely distribute the URL identifying the publication in the public portal

If you believe that this document breaches copyright please contact us providing details, and we will remove access to the work immediately and investigate your claim. 


\section{Business Process Management and IT Management: The Missing}

\section{Integration}

Abstract: The importance of business processes and the centrality of IT to contemporary organizations’ performance calls for a specific focus on business process management and IT management. Despite the wide scope of business process management covering both business and IT domains, and the profound impact of IT on process innovations, the association between business process management and IT management is under-explored. Drawing on a literature analysis of the capabilities of business process and IT governance frameworks and findings from a case study, we propose the need for horizontal integration between the two management functions to enable strategic and operational business-IT alignment. We further argue that the role of IT in an organization influences the direction of integration between the two functions and thus the choice of integration mechanisms. Using case study findings, we propose that IT as a business enabler respectively calls for sequential and reciprocal integrations at strategic and operational planning levels. Drawing on logical reasoning, we suggest that IT as a strategic driver necessitates reciprocal integration at both levels.

Keywords: Alignment, IT Governance; Business Process Governance; Business Process Management; Information Technology Management 


\section{Introduction}

Information technology (IT) offers a wide range of opportunities to organizations for automating, informing, and transforming their business. Promoted by the increasing centrality of IT to business performance, a rich body of literature has centered on management practices that affect the quality and range of IT’s impacts. Among these practices, IT governance (ITG)1aims at enabling effective use of IT by coordinating IT decision making across business and IT communities (De Haes \& Van Grembergen, 2009; Peterson, 2004). While such governance mechanisms only facilitate coordination between business and IT decisions, a different element - business processes - ties the business and IT worlds together (Harmon, 2010). Business processes link business strategy to an organization’s IT capabilities. Davenport (1993) acknowledges that process enforcement technologies hold the potential to provide the so-called "missing-middle" to overcome the businessIT divide. The importance of business processes in contemporary organizations has also given rise to business process management (BPM) as a management technique that ensures continuous optimization of an organization's business processes. Indeed, given the growing pervasiveness of IT-enabled business processes, BPM and IT management studies have been tightly integrated.

Numerous studies have recognized the interdependencies between IT systems and business processes (e.g. Smith \& Fingar, 2003; Tarafdar \& Gordon, 2007). On the one hand, IT implementations are one of the driving forces for business process reengineering in organizations (Irani, 2002). In addition to avoiding costs incurred by system customization, IT-driven approach toward BPM enables business process innovation in line with industry best practices and emerging IT trends (Smith \& Fingar, 2003). On the other hand, comprehensive business process designs that reflect business requirements can be transformed into technical specifications to inform system 
selection, configuration, and integration (Lee, Siau \& Hong, 2003; Rosemann, 2010). In this way, process-driven IT management ensures alignment of IT decisions with business objectives. Because of these interdependencies, several studies have emphasized the need for IT roles involvement in BPM activities on the one hand, and process roles inclusion in IT decision making on the other (e.g., Doebeli, Fisher, Gapp \& Sanzogni, 2011; Hammer, 2004; Spanyi, 2010; Tarafdar \& Gordon, 2007; Scheer \& Brabänder, 2010; Weill and Ross, 2004).

However collaboration between BPM and IT management functions is not reflected in their governance frameworks. ITG frameworks are built around active involvement of business parties in IT decision making (e.g., De Haes \& Van Grembergen, 2009; Peterson, 2004), but they overlook the role of BPM functions in making and monitoring IT decisions. This disconnect is also true for business process governance (BPG) frameworks. Although IT often influences and is influenced by business processes, BPG frameworks fail to specify the involvement of IT roles in BPM decision making. Failure to include process roles in IT decision making may lead to strategic misfits between business and IT (Smith \& Fingar, 2003), loss of competitive advantages (Lee et al., 2003), and “technology fixation” (Scott, 1999). Disregarding IT roles in BPM decision making results in complex IT architecture (Fonstad \& Robertson, 2006), and higher risk, complexity, and financial costs of IT implementations (Beatty \& Williams, 2006).

In this study, we examine the integration of BPM and IT management functions and particularly how BPG and ITG, as two distinct governance frameworks, support the collaboration between the two management functions. Drawing on horizontal job specialization between BPM and IT management functions, complexity of their work, and great business process and IT system interdependencies, we expect close coordination and mutual adjustment between BPM and IT management functions. Therefore, we anticipate the need for alignment and interoperability of BPG and ITG frameworks. We examine these premises by asking and answering two questions: Why and 
how do BPM and IT management functions collaborate? We answer the first question by building linkages between the BPG and ITG literature to identify the shared responsibilities between BPM and IT management functions. We then empirically investigate such joint responsibilities and the governance mechanisms that enable integration via a case study of a multinational corporation with relatively mature BPG and ITG structures and decision-making processes.

The remainder of the paper is organized as follows: In section 2 we describe BPG and ITG based on a literature review, and in section 3 our research methodology. Section 4 discusses our findings for the overlapping accountabilities within the BPG and ITG frameworks. Drawing on the case study, section 5 provides evidence of the mechanisms that enable integration between BPM and IT management functions. In section 6 we present a model to frame integration of the two functions. Sections 7 and 8 conclude with a discussion of findings, contributions, limitations, and potential extension of the research.

\section{Theoretical Background: Defining BPG and ITG}

Governance, which is the organization of management, comprises the set of goals, principles, organizational charts, policies, and rules that define or constrain what managers can do (Harmon, 2008). This section briefly describes BPG and ITG as the overarching guidelines for management of business processes and IT assets.

\subsection{Business Process Governance}

BPM is a structured management approach that uses methods, policies, metrics, management practices, and software tools to coordinate all aspects of the specification, design, implementation, operation, measurement, analysis, and optimization of business processes (Davis \& Brabänder, 
2007). As one of the six core elements critical to building BPM maturity (Rosemann \& Vom

Brocke, 2010), BPG is accountable for managing the BPM process (Kirchmer, 2011).

BPG refers to the establishment of relevant and transparent accountability and decision-making processes to guide desirable process actions (De Bruin, 2009; Doebeli et al., 2011; Scheer \& Brabänder, 2010). Table 1 provides an overview of the two principal governed BPG capabilities, that is, capabilities that prescribe the essential activities to be performed within the BPM discipline.

\begin{tabular}{lll}
\hline Governance & Description & Example \\
Capabilities & & \\
\hline Structure & Organizational structure for people involved & BPM sponsor \\
& in BPM activities and the scope of their tasks & Head of BPM \\
& BPM steering committee \\
& & BPM center of excellence \\
Processes & Business process experts \\
& Formalization and institutionalization of & Process improvement planning \\
& process-related decision making at various & Strategy and process capability \\
& organizational levels and within and across & linkage \\
business processes and process improvement & Process design \\
\hline projects, along with broader decision making & Process implementation and execution \\
about strategic direction and development of & Process control and measurement \\
\hline BPM & \\
\hline
\end{tabular}

Table 1: Business process governance capabilities (De Bruin, 2009; Kirchmer, 2011; Santana, Alves, Santos \& Felix, 2011)

The structure and processes within a BPG framework ensure setting, monitoring, and directing of BPM strategy, overseeing and aligning all BPM-related activities and projects, designing and 
driving implementation of business processes, providing required resources and IT systems, inspecting and auditing process execution and performance, and initiating process improvements (Burlton, 2010; Hammer, 2001; Kirchmer, 2011).

\subsection{IT Governance}

ITG is the framework for the distribution of decision-making rights among stakeholders and the procedures and mechanisms for making and monitoring IT decisions (Peterson, 2004). The purpose of ITG is to encourage desirable behavior in the use of IT (Weill \& Ross, 2004) and to ensure that an organization's IT sustains and extends the organization's strategies (ITGI, 2003). Table 2 presents the structure and decision-making and monitoring processes that constitute ITG.

\begin{tabular}{lll}
\hline Governance & Description & Example \\
Capabilities & Organizational structure for people involved & IT strategy committee at board level \\
\hline Structure & IT IT management activities and their & IT project committee \\
& decision-making rights & Architecture steering committee \\
& CIO on executive committee \\
& IT relationship managers \\
& Formalization and institutionalization of IT & Strategic information system planning \\
Processes & IT security steering committee \\
\hline procedures. & Center of competence and excellence \\
& IT portfolio management \\
& IT performance measurement \\
\hline
\end{tabular}


Table 2: IT governance capabilities (De Haes \& Van Grembergen, 2009; Peterson, 2004; Weill \& Ross, 2004)

The ITG structural and process mechanisms ensure defining and directing of IT strategy and principles, determining business priorities in IT investments, managing IT-related risks and security issues, managing IT performance measurement, and monitoring delivery of business benefits during and after implementation of IT investments (De Haes \& Van Grembergen, 2009; Weill \& Ross, 2004).

\section{Research Methodology}

We conducted this study in three stages as depicted in Figure 1. This section briefly presents the research methodology in each stage.

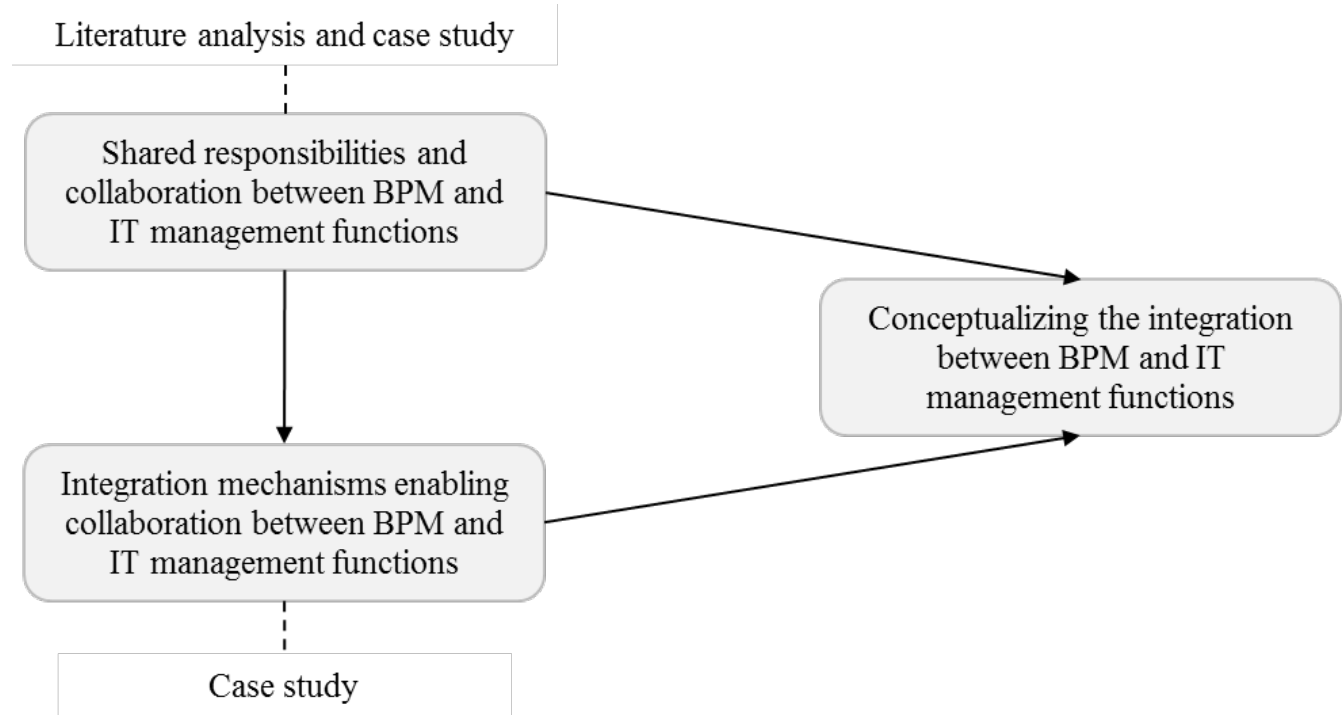

Figure 1: Methodology and contribution of paper

First, to understand the accountabilities and decision domains in BPM and IT management and to identify their integration points, we investigated BPG and ITG studies identified through a structured literature search in Web of Science and Scopus. As illustrated in Table 3, while ITG has 
been heavily examined for almost two decades, BPG has received significantly less attention from academia, despite the substantial number of studies on BPM. However, additional papers on BPG were identified in the Handbook on Business Process Management (Vom Brocke \& Rosemann, 2010), and more papers on BPG and ITG were included by citation trailing the literature found during the structured search. We then carefully analyzed the selected papers with respect to BPG and ITG decision domains and accountabilities. Our comparative analysis revealed an overlap in the accountabilities specified within the two governance frameworks with respect to business-IT alignment and IT-enabled business value realization. This potentially answers the question of why BPM and IT management functions collaborate. Result of this analysis is presented in section 4.

\begin{tabular}{|c|c|c|c|c|}
\hline Topic & Keywords & Scopus & $\begin{array}{l}\text { Web of } \\
\text { Science }\end{array}$ & $\begin{array}{l}\text { Refined selection } \\
\text { based on title and } \\
\text { abstract }\end{array}$ \\
\hline$\overline{\text { BPG }}$ & $\begin{array}{l}\text { Business process governance; Process } \\
\text { governance; Governance of business } \\
\text { processes; Governance of processes; } \\
\text { Business process management governance; } \\
\text { Governance of business process } \\
\text { management; BPG; BPM governance }\end{array}$ & 52 & 22 & 13 \\
\hline ITG & $\begin{array}{l}\text { Information technology governance; IT } \\
\text { governance; Information systems } \\
\text { governance; IS governance }\end{array}$ & 224 & 126 & 40 \\
\hline
\end{tabular}

Table 3: Number of papers on BPG and ITG topics found during structured literature search

Second, for purposes of examining and validating findings from the literature analysis and to understand how BPM and IT management functions collaborate, we conducted a single in-depth case study. The choice of methodology can be justified given the exploratory nature of the study, 
our focus on organizational aspects of BPM and IT management, and our objective of understanding relationship between BPM and IT management functions in conjunction with their context (Benbasat, Goldstein \& Mead, 1987; Corbin \& Strauss, 2008; Orlikowski, 1992; Yin, 2009). The organization selected is a multinational corporation with both BPG and ITG frameworks in place. The corporation has been actively managing its business processes for more than 15 years, relying on well-developed BPG decision-making processes and structure. We were also aware that corporate-wide ITG had been formalized over the previous seven years to enable deployment of a unified IT solution across corporate business units. Therefore, the selected organization is an information-chosen case.

We consider the case to be archetypical, exemplifying corporations with centralized, mature, and distinct BPG and ITG arrangements, where IT plays a reactive role and has negligible influence on business strategy. We expect both BPG and ITG characteristics to influence integration between BPM and IT management functions. Researchers generally agree on the influence of organizational structure and competitive strategy on approach toward ITG adoption whereas no significant association is found between ITG design and an organization's industry type and size (Brown \& Grant, 2005). The studies by Henderson and Venkatraman (1993) and Teo and King (1997) also highlight the impact of IT role on direction of integration between business and IT. We did not identify any situational studies on BPG, but Melenovsky (2006) suggests BPM maturity influential on organizations approach toward BPG structuring and staffing. This is also in line with our experience researching BPM. In less mature cases we have usually found BPM function embedded within IT organization and only responsible for requirements engineering during IT projects, whereas in more mature cases a distinct BPM function typically has the accountability for managing business processes along their lifecycle. 
Having both BPG and ITG in place, the selected organization is an appropriate case for studying potential collaborations between BPM and IT management functions and the associations between their governance frameworks. We may as well consider the case to be critical because if the findings from this single case illustrate collaboration between BPM and IT management functions, then the study will indicate the necessity of integration between BPG and ITG frameworks.

We used interviews as the primary method for gathering data. At the start, we structured the interview guide in an explorative manner to provide the interviewees with opportunities to elaborate on corporate BPM and IT management, but as we discovered more on the nature of linkages between BPM and IT management functions, the interview questions became more focused. In line with our research question, we investigated corporate BPG and ITG structures and decision-making processes, probed any collaboration between BPM and IT management functions, and explored structural and process integration mechanisms that facilitated the collaboration. Our agenda did not include relational integration mechanisms. Between September 2012 and November 2013, the first author conducted nine interviews with corporate process and IT representatives including the process owner, process manager, business relations manager, delivery area manager for operations, business relations manager for sales, and the two corporate BPM framework drivers. (Note: Two persons were interviewed twice.) The duration of each interview varied from one to two hours. Follow-up questions supplemented the interviews occasionally to resolve ambiguities and inconsistencies. Interviewing members of both BPM and IT management functions, we expect to have compensated for potential biases in interviewees’ perception toward the role of their function in business-IT collaborations (e.g. Tracy, 2010). To obtain convergent validation from various data sources, we also collected data from archival sources describing BPG structure and ITG decisionmaking framework, and narratives and some interview transcripts from the second author's earlier longitudinal study of the corporation. 
We then carried out the data analysis in three stages. First by aggregating interview transcripts and archival sources, we developed a set of narratives that described governance of BPM and IT management in the corporation. These narratives also included details about collaborations between BPM and IT management functions. To enhance confidence in findings, we shared and discussed the narratives with two of the interviewees: one from BPM function and one from IT management function. A summary of these narratives is presented in section 5. Second, coding and analyzing the case data and inspired by previous studies on business-IT alignment, we identified two properties that characterized integration between corporate BPM and IT management functions: planning level of integration and direction of integration. Third, facing variations in direction of integration at different planning levels, we further analyzed the case data to identify the contextual factors that caused the difference. Inspired by previous studies on business-IT alignment (e.g. Henderson \& Venkatraman, 1993; Teo \& King, 1997; Weiss, Thorogood \& Clark, 2006), we found the role of IT influential on integration direction between the two functions. The detailed description of these concepts is presented in subsection 5.4. We selected the three concepts of planning level of integration, direction of integration, and role of IT to develop a model that explained integration between BPM and IT management functions. Results of this analysis appear in section 6 .

\section{Literature Analysis: Why Do BPM and IT Management Functions}

\section{Collaborate?}

We consider BPG and ITG subset disciplines of corporate governance. An organization’s critical dependencies on IT suggest that ITG must be an integral part of corporate governance and a primary concern of the board of directors (Van Grembergen, De Haes \& Guldentops, 2004; Weill \& Ross, 2004). Encompassing the same factors as the more traditional corporate and IT governance, BPG is also a subset of corporate governance with a focus on intangible process assets (Doebeli et 
al., 2011; Hammer \& Stanton, 1999; Markus \& Jacobson, 2010). In addition, we consider BPG and ITG to be distinct governance frameworks. While IT is an important enabler for process redesign, BPM is a holistic approach to the management of process change with customer and employee issues as important as IT issues (Harmon, 2010; Masli, Richardson, Sanchez \& Smith, 2011). Meanwhile, important interdependencies between business processes and IT systems suggest the need for interoperability between the two governance frameworks.

Our comparative analysis of BPG and ITG literature revealed overlap in the responsibilities specified within the two frameworks. BPM and IT management functions share responsibility for business-IT alignment and IT-enabled business value realization. Building on this finding, we suggest the need for integration between the two functions to collaboratively accomplish the shared responsibilities. The next two subsections elaborate on our arguments for overlapping accountabilities. Each subsection aggregates and contrasts the studies on BPG and ITG with respect to that specific responsibility to depict overlap in the accountabilities of BPM and IT management functions.

\subsection{Business-IT Alignment}

Business-IT alignment is the process of achieving competitive advantage by developing and sustaining a symbiotic relationship between business and IT (De Haes \& Van Grembergen, 2009). Luftman and Brier (1999) define business-IT alignment as applying IT appropriately and in a timely manner, in harmony with business strategies, goals, and needs. Studies thus far have suggested responsibility for business-IT alignment in both BPG and ITG frameworks.

The definition of ITG explicitly underlines business-IT alignment as the ultimate outcome of enterprise governance of IT (Van Grembergen \& De Haes, 2009). Highly aligned organizations appear to leverage more mature ITG practices (De Haes \& Van Grembergen, 2009). ITG process 
integration mechanisms enable the alignment of business and IT decisions (Peterson, 2004). Furthermore, the use of liaison positions and a mix of business and IT executives in ITG structure enhance IT managers' understanding of business needs and allow business managers' proactive behavior (Peterson, 2004).

ITG accountability for business-IT alignment clearly overlaps with Spanyi’s (2010) description of an essential role for BPG: ensuring that IT investments support the organization's business strategy. To ensure business-IT alignment and the "right type of fit” between business and IT, the overall business strategy must be directly tied to various IT initiatives through business processes and their information requirements (Feurer, Chaharbaghi, Weber \& Wargin, 2000; Luftman, 1996; Tallon, 2007; Trkman, 2010). As a BPM function is responsible for design and implementation of business processes (Kirchmer, 2011), accountability for linking business strategy to IT initiatives naturally falls within the BPG framework.

ITG frameworks are built around the involvement of both business and IT parties in IT decision making to ensure business-IT alignment. Business roles involved in IT decision making are responsible for establishing and communicating strategic direction to IT leaders, and participating in strategic and operational IT decision making for IT principles, IT architecture, IT investment and prioritization, and business application needs (ITGI, 2003; Rau, 2004; Weill \& Ross, 2004). Although the ITG research emphasizes the critical role of business parties in business-IT alignment, they do not discuss the contribution of process roles.

Meanwhile, according to BPM research, the general business process structure and strategy, underlying application system architecture, and alignment between the two are decided at the strategy layer of BPM (Burlton, 2010; Tučková \& Tuček, 2011). Aligning BPM efforts to strategic business and IT goals, choosing the optimal mix of IT investments based on their contribution to 
business process improvement, and providing the demand analysis and blueprint for IT implementations are some of the IT-related responsibilities of process roles (Hongjun \& Nan, 2011; Korhonen, 2007; Novotny \& Rohmann, 2010; Scheer \& Brabänder, 2010; Trkman, 2010; Tučková \& Tuček, 2011). Therefore, Luftman and Brier (1999) suggest business process managers as typical members of business-IT alignment teams.

Our comparative analysis demonstrates that both BPM and IT management functions are held accountable for business-IT alignment. This indicates important interdependencies between the two functions and the necessity of aligning their governance frameworks.

\subsection{IT-enabled Business Value Realization}

IT business value refers to the performance impact of IT at the organization and intermediate process levels (Melville, Kraemer \& Gurbaxani, 2004). Evidence shows that IT competencies positively influence organizational performance (Tallon, Kraemer \& Gurbaxani, 2000; Tarafdar \& Gordon, 2007). Yet, as IT benefits become primarily absorbed into business processes, it is difficult to identify how IT provides value (Wilkin \& Chenhall, 2010). IT value delivery deals with executing the value proposition throughout the delivery cycle and ensures that IT delivers its promised benefits (Posthumus, Von Solms \& King, 2010). The BPM and IT literature suggest responsibility for IT business value delivery within both BPG and ITG frameworks.

On the one hand, IT value delivery is among the principal facets of ITG (Van Grembergen et al., 2004; Wilkin \& Chenhall, 2010). Charge-back arrangements, IT performance measurement in terms of business benefits, and benefit management and reporting during and after implementation of IT projects are some of the ITG processes that enable IT business value delivery (De Haes \& Van Grembergen, 2009; Peterson, 2004; Spremić, 2009). Research on ITG argues that only business managers and users can be held accountable for realization of business benefits enabled by IT 
investments, and therefore call for their higher level of involvement in IT projects (e.g., Weill \& Ross, 2009). More specifically, Rau (2004) assigns accountability for realization of IT-dependent business goals to non-IT roles with a seat in ITG structure. This is because benefits from IT investments mainly emerge from changes to ways of working and only those who instigated these changes can realize the benefits (Peppard, Ward \& Daniel, 2007; Wilkin \& Chenhall, 2010).

On the other hand, Spanyi (2010) suggests an essential role of BPG to ensure that the payoff from IT investments is directly derived from specific improvements in business process performance. As first-order impacts of IT arise at the business process level (Melville et al. 2004; Tallon, 2007), IT business value will only emerge when new and adequate business processes are designed, executed, and monitored (Masli et al., 2011; Spremić, 2009; Van Grembergen \& De Haes, 2009). Because accountability for ensuring the proper design, implementation, execution, and monitoring of business processes falls within BPG frameworks (Kirchmer, 2011), BPG must obviously comprise the monitoring processes for IT business value delivery. BPG is the essential foundation to ensure sustainability of process innovation and improvements and continuous focus on creating value for all stakeholders (Krichmer, 2010; Tregear, 2009). More specifically, it is typically the responsibility of process owners to monitor the operating performance and continuous improvement of business processes by which the organization delivers value (Scheer \& Brabänder, 2010). These arguments suggest process roles responsible for making effective use of the technology for executing business processes to realize IT-enabled business value.

Again a comparison among accountabilities specified in the two governance frameworks indicates that responsibility for IT-enabled business value delivery resides both with the process roles specified within a BPG framework and non-IT roles involved in IT decision making. This suggests the need for coordination and integration between BPM and IT management functions for ITenabled business value realization. 


\section{Case Study: How Do BPM and IT Management Functions}

\section{Collaborate?}

Findings from our comparative literature analysis on ITG and BPG suggest an overlap in the accountability of BPM and IT management functions for business-IT alignment and IT-enabled business value realization. This raises the question of how BPG and ITG frameworks enable collaboration between BPM and IT management functions for accomplishing the joint accountabilities. To answer this question, we investigated Gamma, which is a leading multinational corporation with a long history in actively managing its business processes and IT systems.

Gamma is represented by 80 companies in more than 55 countries. Business units are specialized by sales offices, production plants, and distribution centers. Consistent with its specialized resource configuration, the corporate organizational structure is a functional one wherein sales and marketing, operations, business development, finance, and people and strategy constitute the main functional domains.

In 1995, Gamma started a journey towards business excellence. The excellence program led to several other initiatives in the corporation, including a new discipline for managing business processes. Perceiving business processes as the means for strategy execution, Gamma set up a welldefined governance structure in which the functional managers were specifically tasked with managing business processes within respective business areas.

Approaching the year 2000 and the Y2K challenge, Gamma launched another project to implement a single-instance Enterprise Resource Planning (ERP) system across business units, which accelerated the BPM effort. Rolling out the single-instance ERP was not only about technology standardization, but about business process standardization and data integration. Consequently Gamma developed a global template of best practices to be rolled out across the corporate business 
units. The unification of IT solutions also demanded centralized IT decision making; therefore Gamma established a centralized ITG structure comprising business and IT representatives from corporate, regional, and local levels. The centralized ITG has since improved IT alignment with corporate business strategy. However, situated within corporate Finance, IT has a limited role in driving business strategy, and product and service development.

The next subsections present a brief description of the two governance frameworks, followed by a description of the devices that integrate BPM and IT management functions in Gamma. Throughout this section the term "process governance" refers to the roles and decision-making processes for the management of business processes, whereas the term "IS governance" reflects the governance structure and processes for directing IT management. As the interviewees mostly originated from operations, the findings likely best represent the governance frameworks in this functional domain, which has the longest BPM history in Gamma.

\subsection{Process Governance}

BPM is an integral part of Gamma's management. Rather than considering BPM an isolated initiative for process improvement, Gamma treats BPM as a holistic approach to ensure the continuous adaptation of business processes to the changing environment. Achieving this requires a clearly described governance embedded in the organizational structure. In Gamma, first and foremost, the executive vice president owns the business processes, indicating BPM sponsorship at the highest level of corporate management as suggested by Doebeli et al. (2011) and Scheer and Brabänder (2010). The executive vice president delegates responsibility for management of business processes and BPM activities to senior functional managers. Figure 2 illustrates the process roles and committees responsible for BPM in each functional domain. 


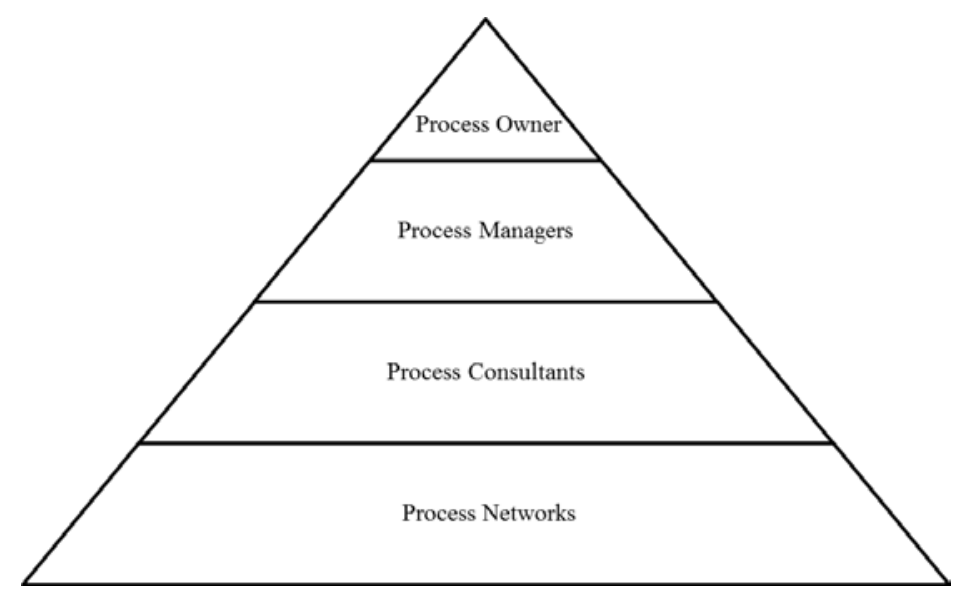

Figure 2: Process organization in Gamma

In each functional domain, the functional vice presidents or their directors assume the role of process owners. In this way, the overall responsibility for BPM is assigned to senior managers who are also in charge of formulating functional business strategy. Consistent with Burlton’s (2010) description of the role of a process executive, Gamma's process owners manage a logical group of business processes at the value chain level and are responsible for their overall performance. They define strategies and translate them into action for various process areas, drive the execution of BPM initiatives within their respective function, and monitor performance of corporate business units.

Each process owner heads a group of process managers, each accountable for a specific process area. Working more at an operational level, business process managers are the ones responsible for activities along the BPM cycle. This is in line with Burlton’s (2010) definition of process stewards and Hammer and Stanton's (1999) definition of process owners: those responsible for design of business processes and their guides and enablers, and assessment of their continuous fitness to the business requirements. Process managers also assist the process owners with the strategy development. Each process manager together with a few process consultants drives one or more process networks comprising representatives from regions or local business units. Representatives 
in a process network are responsible to communicate the process requirements of their respective region or business unit and assist the process manager with design and improvement of business processes.

\subsection{Information System Governance}

IS governance in Gamma is a part of corporate governance. It follows a hybrid model and is structured around the five IT decision domains suggested by Weill and Ross (2004). While the corporate IT managers hold decision-making rights for IT architecture and infrastructure, the corporate and local business representatives play a major role making decisions about IT project prioritization and business application needs, and providing input for IT principles, IT investment, and IT architecture decision making. Figure 3 illustrates Gamma’s IS governance structure that brings together business representatives and corporate IT managers and consultants.

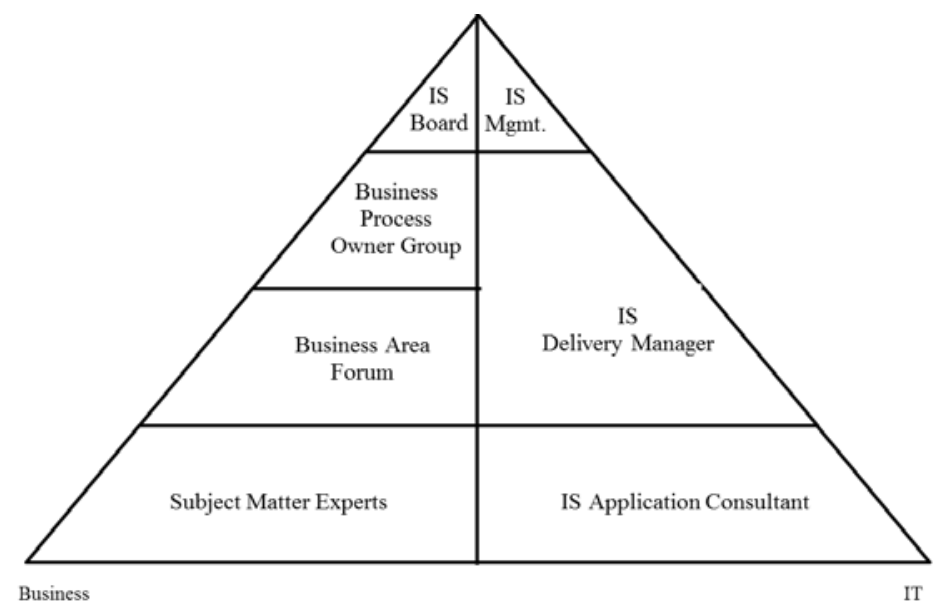

Figure 3: IS organization in Gamma

A business process owner group, a few business area forums, and several subject matter expert groups represent each functional domain in the IS governance structure. The business process owner group, comprising the functional vice presidents, their directors, or both, and in some cases the global or local managers, are responsible for communicating the functional business strategy to 
set the direction for defining IT strategy. Other responsibilities of these groups include managing the IT projects portfolio and IT budget for their respective function. Members of a business process owner group join their functional middle managers in the business area forums where there is a more dedicated focus on the IT strategy for a specific business area. Cooperating more at an operational level, the subject matter expert groups communicate the business process requirements at the global and local levels to the IS consultants to guide the application development and configuration.

The IS delivery managers own the IT delivery area strategy. The IS reference board - consisting of the chairpersons of business process owner groups, $\mathrm{CIO}$, and business relations managers - is in charge of cross-functional IT business projects, consolidation of the IT business project portfolio, and managing the overall budget for IT projects. On the other hand, IS management with the participation of the CIO and IT directors make decisions on technical aspects of IT projects.

\subsection{Integration between Process Governance and IS Governance}

In Gamma, two distinct but tightly integrated governance frameworks direct BPM and IT management. As illustrated in Figure 4, some of the business liaison positions in the IS governance structure are held by the business representatives who also seat in the process governance structure. While their responsibility in the IS governance framework is limited to IT decision making, in the process organization they are responsible for the broader aspects of design, control, and optimization of business processes. 


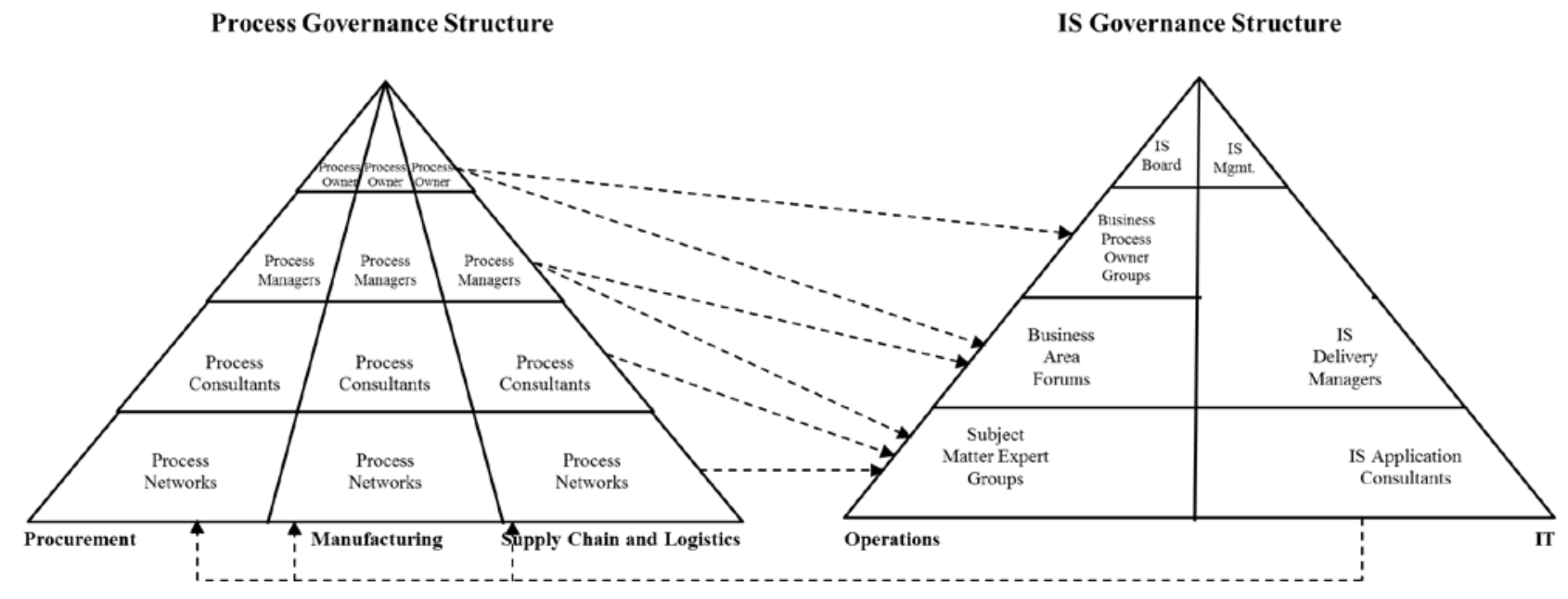

IS Governance Committees

\begin{tabular}{|l|c|c|c|c|}
\cline { 2 - 5 } \multicolumn{1}{c|}{} & IS Board & $\begin{array}{c}\text { Business Process } \\
\text { Owner Group }\end{array}$ & $\begin{array}{c}\text { Business Area } \\
\text { Forum }\end{array}$ & $\begin{array}{c}\text { Subject Matter } \\
\text { Expert Group }\end{array}$ \\
\hline Senior Process Owner (Functional Vice President) & $\mathrm{X}$ & $\mathrm{X}$ & & \\
\hline Process Owner (Functional director) & & $\mathrm{X}$ & $\mathrm{X}$ & \\
\hline Process Manager & & & $\mathrm{X}$ & $\mathrm{X}$ \\
\hline Process Consultant & & & & $\mathrm{X}$ \\
\hline Process Network & & & & $(\mathrm{X})$ \\
\hline
\end{tabular}

Figure 4: Integration between process governance structure and IS governance structure in Gamma

Each functional business process owner group in the IS governance structure comprises that functional area's process owners. The process owners are also included in the various business area forums. Process managers may also be present in the business area forums. Process managers and process consultants, potentially together with respective process networks of local or regional representatives, fill in the various subject matter expert groups situated within the IS governance structure.

Taking the business liaison positions in the IS governance structure, the process roles have the official authority to align IT decisions with those in the process organization. At the strategic level, the process owners direct the IT strategy based on the business strategy and BPM plans. At the operational level, the process managers and consultants guide the IT system design and application configuration based on process requirements. We also found that the IS consultants are involved in 
BPM activities. IS consultants not only collect process requirements, but are also involved in process design and development from early stages, and provide the process roles with an understanding of IT systems’ potential support for business processes. They may even direct process design activities based on the best practices embedded in IT systems. However, while actively assisting business process managers and process networks in BPM decision making, IS consultants’ position in the process governance structure is not well formalized.

In line with our findings from the comparative literature study, in Gamma the collaboration between process and IS organizations enables business-IT alignment. The case study shows that the business liaison positions in the IS governance structure taken by process roles and less formalized IT liaison positions considered in the process governance structure facilitate joint decision making for IT principles, IT investments, IT architecture, business application needs, and process design.

Managing IT-enabled business value realization is still a novel concept in the corporation; therefore, no role within process or IS governance structures has the clear responsibility for IT business value delivery.

\subsection{Properties of Integration between Process Governance and IS Governance}

In the next step of data analysis we examined the case data to identify properties of integration between process and IS organizations. We especially investigated governance mechanisms that enabled involvement of process roles in IT decision making and those that facilitated engagement of IS managers and consultants in BPM activities. This analysis led to identification of two integration properties: the direction of integration, and the planning level at which process and IS organizations integrate. Noticing a difference in direction of integration at strategic and operational planning levels, we further analyzed the case data and identified IT role as the mediating factor. Figure 5 provides a more detailed description of concepts emerged during open and axial coding. The first- 
order concepts emerged from open coding raw data; comparing and contrasting these concepts led to the emergence of second-level themes; and an aggregation of these themes were used to define the properties of the focal concept, namely integration between BPM and IT management functions. While these properties emerged from the case data, especially after visualizing the interactions in Figure 4, we were also inspired by previous studies on business-IT alignment when characterizing them (e.g. Henderson \& Venkatraman, 1993; Tarafdar \& Qrunfleh, 2009; Teo \& King, 1997; Weiss et al., 2006). The next three subsections describe the three concepts as the axes of understanding integration between BPM and IT management functions. 
- IT connects to business at business strategy and business process levels - IS organizations integrate to process organization at two levels: high level by business relation managers and detailed level by IS application consultants

- IT invites business process owner group for IT strategy development - At business process owner group level business strategy is translated into IT requirements

- Business process owner group and business area forum have input right for IT architecture, IT investments and prioritization, IT principles, and have the decision making right for business application needs

- Subject matter expert group evaluates, approves, and prioritizes smaller IT change requests

- Subject matter expert group and IS application consultants have input right for business application needs

- Subject matter expert group details requirements for IT solutions

- IT invites business process owner group for IT strategy development - Business process owner group and subject matter expert group have input or decision right for IT principles, IT architecture decisions, and IT investments

- Strategic themes originate in business, IT enables business themes

- IT only the receiver of business strategy

- IT not involved in business strategy development

- IT challenges business requirements to safeguard IT landscape

- IT may provide feedback for business strategy

- IT strategy developed based on business strategy

- IT application consultants involved in defining the template and best practices

- More business process reengineering than ERP development

- ERP best practices inspired defining best processes

- IT involved in process design from early stages to discuss system capabilities

- IT has to ask subject matter experts or business process owner group for permission before implementing IT change requests

- Subject matter expert group has input right for business application needs

- Processes are tightly linked to IT

- IT application consultant and process consultant almost married
Contact points between BPM and IT management functions: business strategy and business processes

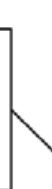
interact with IT at strategic level
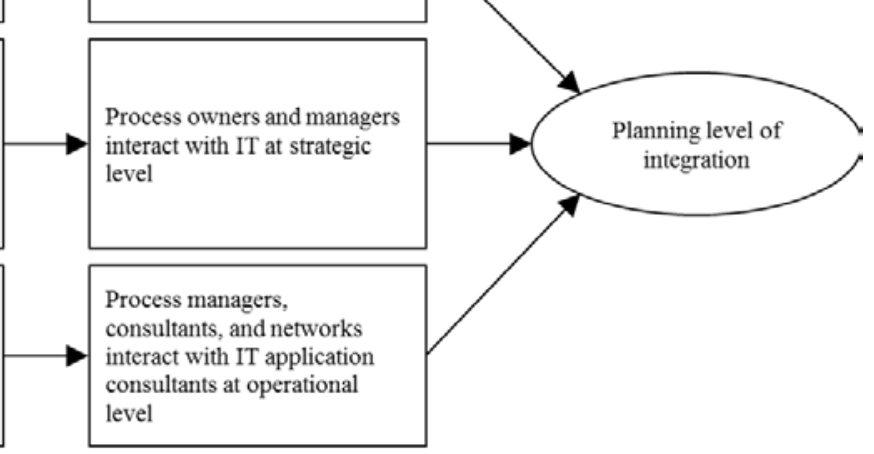

Process managers,

consultants, and networks interact with IT application consultants at operational level

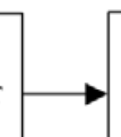

Process roles influence IT strategic decisions

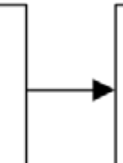

IT has no or limited influence over business strategy

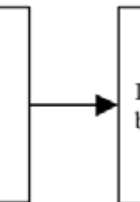

IT involved in process design based on system capabilities
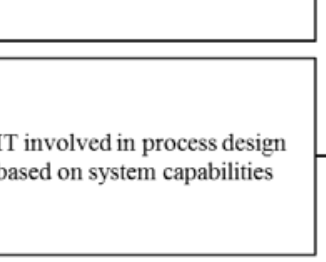

Process roles influence application configuration

Tight integration between BPM and IT management functions at process level

- IT governance ensures IT fulfils business requirements

- IT strategy developed based on business strategy

- Strategic themes come from business, IT enables business themes

- IT only the receiver of business strategy, not involved in business strategy development

- Business drives IT requirements and not reversed

- IT placed under Finance

- More business process reengineering than ERP development - ERP best practices inspired defining template processes - IT involved in process design from early stages to discuss system capabilities

- IT used to be only a supplier, but today IT is a business enabler - IT was not aligned with business, but now business satisfied with IT alignment

- IT to sign service level agreements with business

- Business still perceived a customer to IT by some IT managers

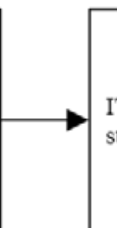

IT reactive to business

strategy
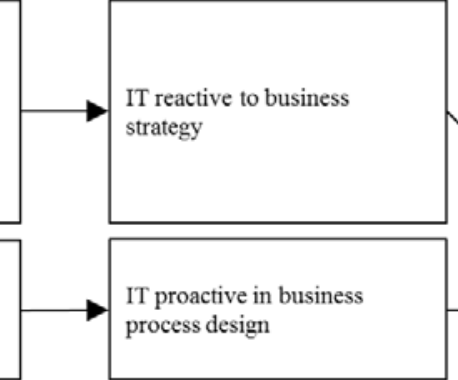

IT proactive in business process design

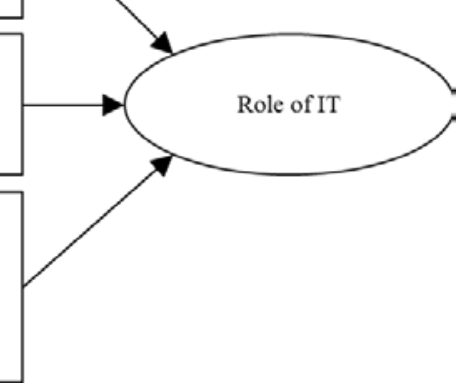

IT transitioned from a

detached supplier to an

integrated business enabler

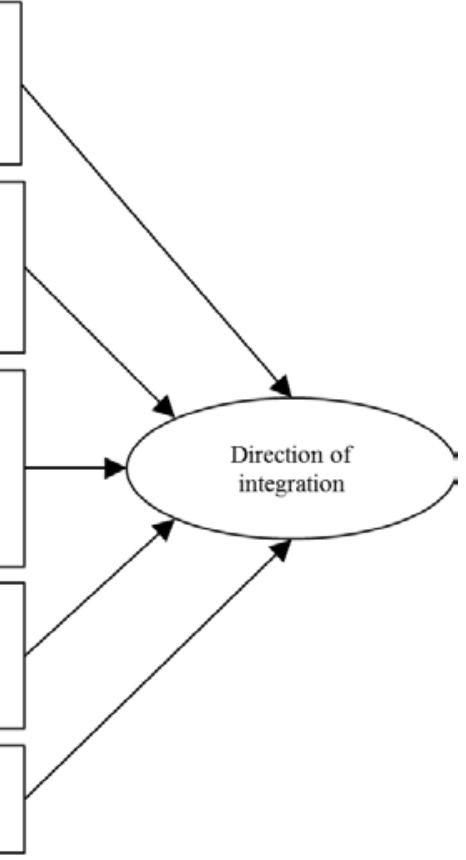




\subsubsection{Planning Level of Integration}

The first property of integration pertained to the planning level at which BPM and IT management functions collaborate. The case study illustrates that the relationship between process and IS organizations is not only a question of strategic but also of operational alignment. At the strategic level, process owners and process managers along with other business executives in business process owner groups and business area forums join the IT managers to translate business strategy into IT strategy and make decisions about IT architecture, and IT investment and prioritization. At the operational level the contacts between IS consultants and process managers, process consultants, and process networks are mainly for joint decision making on business application needs, process design, and IT system design. Figure 5 illustrates the first- and second-order concepts that resulted in the emergence of this property.

While this property emerged from the case data, it is not entirely new. Few studies on business-IT alignment have already distinguished between the strategic and operational dimensions of integrating business and IT (Schwarz, Kalika, Kefi \& Schwarz, 2010; Tarafdar \& Qrunfleh, 2009; Wagner, Beimborn \& Weitzel, 2014). Characterizing this property, we were especially inspired by Tarafdar and Qrunfleh (2009) and their suggestion for a two-level business-IT alignment analysis. While strategic integration ensures alignment between business and IT strategies, operational integration makes sure that the strategically planned applications are effectively deployed (Tarafdar \& Qrunfleh, 2009). The strategic perspective focuses on alignment among high-level executives, and operational alignment is the concern of project teams and IT and business professionals involved in business processes (Wagner et al., 2014). While reinforcing previous studies on the business-IT integration, the case study illustrates a more specific integration between BPM and IT management functions, ensuring synchronization of BPM and IT plans at the strategic level and effective support of IT applications for business processes at the operational level. 


\subsubsection{Direction of Integration}

The second property of integration concerns direction of integration between BPM and IT management functions. Investigating the integration between the two functions at strategic and operational levels, we faced differences at the direction of integration between two levels. At the strategic level, integration between process and IS organizations is sequential: the business strategy and BPM plans direct IT strategy and are indisputable inputs for IT decision making. The IS governance structure includes business liaison positions to enable involvement of business roles, and among all process roles, in IT decision making. In contrast, IT managers have negligible influence on defining the business strategy and developing BPM plans. However, at the operational level, collaboration between process and IS organizations has a reciprocal nature. One the one hand, taking business liaison positions in the IS governance structure, process roles have the possibility to communicate process requirements and application needs, and participate in IT system design. On the other hand, IS consultants also play an active role in influencing process design based on IT systems' capabilities. Indeed IS consultants significantly influence process design based on ERP best practices. Figure 5 provides a more detailed description of the concepts that led to the emergence of this property.

Although this property emerged during data analysis, typifying this property we were inspired by Teo and King (1997) and their concept of direction of integration between business and IT planning processes. One-way reactive or sequential integration was the first attempt for integrating business and IT planning processes to enable deriving IT strategy from business strategy (Teo \& King, 1997). Later the recognition that IT planning can be used not only to support but also to influence business strategies led to the two-way reciprocal integration between business and IT planning (Teo \& King, 1997). Other studies took this concept even further and suggested the concept of full integration, where the IT planning process is indistinguishable from the business planning process 
(Teo \& King, 1997). The case study shows that this concept can also be used to explain the direction of integration between BPM and IT management functions at the strategic and operational planning levels.

\subsubsection{Role of IT in Alignment}

Facing variances in the direction of integration between BPM and IT management functions at the strategic and operational levels, in the third stage of data analysis, we probed the contextual factors that caused the difference. Keeping “constant comparison” in mind (Corbin \& Strauss, 2008), we identified an association between integration direction and the perceived role of IT in business-IT alignment. In the studied organization, IT as a business enabler is aligned with business requirements, not the other way around. Statements such as "the business requires certain things from IT and not reversed" and "whatever the process organization comes up with IT will have to align with” indicate such perceptions toward IT in Gamma. IT is mainly responsible for developing and maintaining "systems of record” and is not a driver of business transformations based on emerging IT trends. Therefore at the strategic level, there is only a sequential integration between the two functions to align IT strategy with business strategy and BPM plans. This one-way alignment is enabled by including process roles in IS governance structure to ensure their involvement in IT strategic decision making.

While IT strategy follows business strategy, we found the IT function to be more proactive at the operational level. On the one hand, process roles have input right for business application needs and configuration. One the other hand, IS consultants are highly involved in designing business processes. Therefore, at the operational level the integration between the two functions is reciprocal, enabled through liaison positions situated within both process and IS governance structures. We associate this to the empowering impact of off-the-shelf IT systems and their embedded best 
practices and functionalities. The rollout of a single-instance ERP was a part of business excellence program in Gamma. To improve integration and exploit economies of scale within business and IT, Gamma needed common standards for business processes and data. Finding a convenient match between business requirements and best practices embedded in the ERP system, Gamma decided to define the global template based on the best practices. In addition, to avoid maintenance issues, the ERP implementation strategy strictly forbade any custom code development unless the system did not meet critical business requirements. These have empowered the IS consultants to play an active role in business process design to enforce the standard IT solutions.

Identifying IT role as the mediating factor, we were inspired by previous studies that investigated the role of IT in various business-IT alignment scenarios. Teo and King (1997) highlight the association between strategic potential of IT and business-IT integration forms. Henderson and Venkatraman (1993) distinguish between four perspectives for aligning business and IT strategies and organizational and IT infrastructures, depending on whether business is the driving force for IT capabilities or IT is the enabler of new business strategies and structure. Weiss et al. (2006) as well define three business-IT alignment profiles: technical resource, business enabler, and strategic weapon. They describe these profiles in terms of the degree of IT alignment internally with the business, and externally for market engagement. Our analysis suggests the role of IT to also explain our focal concept, namely integration between BPM and IT management functions.

\section{Conceptualizing Integration between BPM and IT Management}

\section{Functions}

Findings from the case study indicate that integration between BPM and IT management functions to support business-IT alignment can be explained by integrating three concepts: the planning level 
of integration, direction of integration, and role of IT. In this section, we use the three concepts to conceptualize the integration between the two functions.

Henderson and Venkatraman’s (1993) strategic alignment model suggests the need for a strategic fit between business and IT strategies and business and IT structure and processes. Given this model, we argue that the way an organization positions itself to shape and enact the business strategy through IT influences integration between business and IT organizational structures — herewith the integration between BPM and IT management functions. Adopting Weiss et al.'s (2006) notion of the alignment profile, we argue that the integration between BPM and IT management functions must be adjusted based on the three roles of IT: technical resource, business enabler, and strategic driver. Using the three concepts derived from the case study, we propose a model that explains the integration between BPM and IT management functions in support of business-IT alignment.

To conceptualize the integration, we use analytical generalization (Yin, 2009). In this understanding, the validity of the proposed model does not depend on the representativeness of the case in a statistical sense, but on the plausibility of the logical reasoning (Walsham, 1993). Drawing on a theoretical analysis of the integration properties in relation to the case organization's context, we will make projections about transferability of the findings to other cases. We enfold the extant literature and compare our propositions with existing theories to strengthen internal validity and wider generalizability of the suggested theory.

Table 4 illustrates the proposed model. Our model is based on disaggregating and recombining the dimensions of planning level of integration, direction of integration, and role of IT. The rows represent the IT role and the columns indicate the strategic and operational planning levels of integration. For each combination of the IT role and planning level, we explain the direction of 
integration between BPM and IT management functions in terms of both the structural and process integration.

Planning Level of Integration

\begin{tabular}{|c|c|c|}
\hline & Strategic Planning & Operational Planning \\
\hline $\begin{array}{l}\text { Business } \\
\text { Enabler }\end{array}$ & $\begin{array}{l}\text { Sequential } \\
\text { * BPM involvement in strategic IT } \\
\text { decision making supported through BPM } \\
\text { liaison positions situated in the ITG } \\
\text { structure } \\
\text { * BPM strategic planning directs IT } \\
\text { strategic planning }\end{array}$ & $\begin{array}{l}\text { Reciprocal } \\
\text { * IT involvement in process design and } \\
\text { BPM involvement in IT system design } \\
\text { through IT and BPM liaison positions } \\
\text { respectively situated in BPG and ITG } \\
\text { structures } \\
\text { * Process design both influences and is } \\
\text { influenced by IT system design }\end{array}$ \\
\hline $\begin{array}{c}\text { Strategic } \\
\text { Driver }\end{array}$ & $\begin{array}{l}\text { Reciprocal } \\
\text { * BPM involvement in strategic IT } \\
\text { decision making and IT involvement in } \\
\text { setting BPM strategic plans supported } \\
\text { through BPM and IT liaison positions } \\
\text { situated in the ITG and BPG structures } \\
\text { * BPM strategic planning both influences } \\
\text { and is influenced by IT strategic planning }\end{array}$ & $\begin{array}{l}\text { Reciprocal } \\
\text { * IT involvement in process design and } \\
\text { BPM involvement in IT system design } \\
\text { through IT and BPM liaison positions } \\
\text { respectively situated in BPG and ITG } \\
\text { structures } \\
\text { * Process design both influences and is } \\
\text { influenced by IT system design }\end{array}$ \\
\hline
\end{tabular}

Table 4: Strategic and operational integration between BPM and IT management functions: the role of IT matters

In developing this model, we limit the role of IT to business enabler and strategic driver as described by Weiss et al. (2006). We do not expect any integration between BPM and IT management functions in organizations where IT is solely considered a technical resource. This is 
because such organizations do not deploy IT to support core business processes, but rather to support routine administrative work (Weiss et al., 2006). Considering the significant role of IT in driving and enabling business processes and supporting BPM initiatives (Davenport, 1993; Hammer, 2010, Niehaves, Plattfaut \& Becker, 2012), the absence of IT support for core business processes in an organization may even indicate the absence of a BPM function. Despite the lack of integration between BPM and IT management functions, business and IT organizations may still have limited administrative integration for communicating administrative automation requirements, as described by Teo and King (1997).

In organizations that perceive IT as a business enabler, IT strategy only reacts to business needs (Weiss et al., 2006). When business strategy is the driver of IT strategy, Henderson and Venkatraman (1993) and Ross and Feeny (1999) limit the role of IT managers to strategy implementers who ensure that IT aligns with business strategy. Therefore when organizations use IT as a business enabler, we argue for a sequential integration at the strategic level between BPM and IT management functions. In such cases, as the IT strategy needs to be aligned with the business strategy and thereby BPM plans, the high-ranking process roles are imposed on the ITG structure to communicate the BPM strategy and plans to IT managers and to take part in IT strategic decision making. Because IT strategy is a second-order consequence of business strategy and BPM plans, the process for strategic business and BPM planning provides direction for the strategic IT planning process.

When IT acts as a business enabler, we expect a reciprocal integration between BPM and IT management functions at the operational level. This is because such organizations deploy IT primarily to support core business processes and to improve their performance through greater efficiency and improved customer service (Weiss et al., 2006), and therefore strive for integrated low-cost transaction systems and analytic tools that assist with identifying new customer segments 
and offerings (Weill \& Ross, 2004). Use of off-the-shelf systems such as enterprise resource planning and customer relationship management systems is common to support such strategies (Weill \& Ross, 2004). When implementing such systems, the system development effort is reduced to enabling the required functionality embedded within the systems (Holland \& Light, 1999). Due to limited system design and negative impacts of excessive system adaptation on implementation success (Hong \& Kim, 2002), IT consultants can considerably influence business process redesign based on best practices embedded in such IT systems. Therefore, when IT is used as a business enabler we argue for reciprocal or even full integration between processes for IT system design and process design. To facilitate this, the ITG framework includes BPM liaison positions to enable communicating process requirements, while simultaneously the BPG structure incorporates IT liaison positions to ensure that IT professionals are also involved in process design.

Organizations that use IT as a strategic driver subsume IT into business strategy and exploit it for business transformation and introducing new products and services (Henderson \& Venkatraman, 1993; Weiss et al., 2006). When IT plays a transformational role, the CIO is a valuable member of the executive team, and not only aligns IT with business strategy but serves also as a driver of business strategy (Ross \& Feeny, 1999). In such organizations, IT managers play the role of catalysts who assist business managers to understand potential opportunities and threats from an IT perspective (Henderson \& Venkatraman, 1993). In such cases we argue for a two-way integration between BPM and IT management functions at both strategic and operational levels. Not only the ITG framework includes BPM liaison positions in its structure, but also IT liaison positions are situated in the BPG structure to facilitate IT managers' contributions to strategic and operational BPM decision making. There is also either reciprocal or full integration between BPM and IT strategic planning processes. BPM and IT strategic planning processes are either interdependent, so that IT plans both support and are supported by BPM plans, or fully integrated, so that BPM and IT 
strategic plans are developed concurrently in the same integrated planning process. This is also true for the processes handling business process design and IT system design.

\section{Discussion}

Our comparative literature analysis detected an overlap in accountabilities specified within BPG and ITG frameworks for business-IT alignment and IT-enabled business value realization. While the case study could not support joint responsibility for monitoring business process and IT systems, it illustrated collaboration between BPM and IT management functions for business-IT alignment at the strategic and operational levels. The liaison positions situated in the BPG and ITG structures and the aligned BPM and IT planning processes were the primary enablers for the collaboration. Therefore, while reinforcing previous studies on the importance of business-IT partnership for alignment, we specifically suggest process roles as important stakeholders in business-IT alignment activities. We also suggest coordination and collaboration between BPM and IT management functions to rely on horizontal integration capabilities designated in the BPG and ITG frameworks. While in this study we only focused on structural and process integration capabilities, relational mechanisms that enable cross-domain knowledge sharing and communication are other means to enable collaboration between BPM and IT management functions. Previous studies have already illustrated the importance of relational mechanisms for attaining and sustaining business-IT alignment (e.g., De Haes \& Van Grembergen, 2009).

While recognizing the need for mutual adjustment between BPM and IT management functions for business process and IT decision making, our study suggests that the planning level and direction of integration and thus the choice of integration mechanisms depend on the role of IT in an organization. We suggest that at the strategic planning level, IT as a business enabler requires a sequential integration between BPM and IT management functions, and IT as a strategic driver 
gives rise to reciprocal integration. While sequential integration ensures alignment of IT strategic decisions with business initiatives, reciprocal integration also enables shaping business and BPM strategic initiatives based on new or improved uses of IT. At the operational level, we propose that IT as both a business enabler and strategic driver encourages reciprocal integration between BPM and IT management functions. Reciprocally integrated BPM and IT management functions ensure IT systems design in line with business requirements while simultaneously exploiting IT potentials for improving business processes.

These findings have three theoretical implications. First, our study reinforces earlier studies on business-IT integration, and further suggests process roles as one of the most important stakeholders for enabling business-IT alignment and therefore inclusion of BPM liaison positions in ITG structure. Second, while supporting previous studies that emphasize the importance of IT professionals' understanding of and involvement in business planning and business executives and users’ participation in IT planning to support business-IT alignment (e.g., Teo \& Ang, 1999, 2001; Ranganathan \& Kannabiran, 2004), this study proposes the role of IT as influential in the direction of integration and thereby applicability of these integration mechanisms. Third, while the horizontal integration capabilities in the ITG structure enable involvement of business parties in IT decision making (De Haes \& Van Grembergen, 2009, Peterson, 2004), they are not sufficient to facilitate IT involvement in business and business process decision making. Consistent with Kooper, Maes, and Lindgreen's (2011) proposition concerning ITG inadequacy for information management, we do not consider ITG concerned with the management of business processes. Therefore, because IT typically plays an important role in business process design - as indicated in the case study - and because the growth in digital economy is increasing the importance of IT for business development (Blosch \& Burton, 2015), we suggest the situation of IT liaison positions in business governance structures and herewith BPG structure to enable IT involvement in BPM decision making. 
The low maturity of selected corporation with respect to IT benefit management made it unsuitable to study integration between BPM and IT management functions in support of IT-enabled business value delivery. However, we argue that IT-enabled business value realization can be enabled using BPM and IT liaison positions in ITG and BPG structures and aligning governance processes for IT benefit management and business process monitoring. Indeed, ITG frameworks already include liaison devices in support for IT value delivery (De Haes \& Van Grembergen, 2009). Previous studies also suggest the use of process-level indicators to measure IT-enabled business value (e.g., Masli et al., 2011; Tallon et al., 2000).

\section{Conclusion}

A growing body of literature has emphasized IT involvement in BPM activities on the one hand and process roles engagement in IT decision making on the other. However, we identified limited discussions on why and how BPM and IT management functions collaborate. Drawing on our findings from a comparative literature analysis and case study, we suggest the need for horizontal contacts between BPM and IT management functions to align strategic and operational decisions on business processes and IT. The study also tentatively proposes the need for integration between the two management functions to support IT-enabled business value delivery. We further associate the direction of integration between BPM and IT management functions at strategic and operational levels with the role of IT in an organization. Relying on findings from the literature analysis and the “force of example” (Flyvbjerg, 2006), our study suggests the need for a new perspective defining BPG and ITG frameworks and draws attention to their interoperability to coordinate formal and informal IT and business process decision-making authority across IT and process parties.

While the study provides interesting insights into why and how BPM and IT management functions collaborate, there are certain limitations. Although we consider the single case study sufficient to 
point out neglected integration between BPM and IT management functions and overlooked associations between BPG and ITG frameworks, studies that examine multiple cases are necessary to refine our findings. Additional studies are needed to validate our theory of integration between BPM and IT management functions, especially in the context of organizations where IT actively drives business strategy. Future research may even reveal other contextual factors aside from the role of IT that influence the nature of alignment between BPM and IT management functions. Corporate governance model and BPM and IT management maturity are some potential factors that may influence the integration between BPM and IT management functions.

Next, this study suggests the need for inclusion of IT liaison positions in the BPG structure to enable IT involvement in BPM activities. While there are numerous studies on ITG and its horizontal integration capabilities, BPG has received far less attention from academia. Therefore, future studies could explore the BPG structural, process, and relational integration mechanisms that enable IT involvement in BPM decision making.

Finally, the case selection was not ideal to investigate collaboration between BPM and IT management function for IT-enabled business value realization. While we are still content with our case selection as it could illustrate one aspect of the collaboration, we encourage repeating the study in organizations with a mature approach toward IT benefit management.

\section{Acknowledgments}

This research was funded by GEA Process Engineering A/S and Innovation Fund Denmark. 


\section{References}

Beatty, R. C., \& Williams, C. D. (2006). ERP II: Best Practices for Successfully Implementing an ERP Upgrade. Communications of the ACM 49(3), 105-110.

Benbasat, I., Goldstein, D. K., \& Mead, M. (1987). The case research strategy in studies of information systems. MIS Quarterly 11(3), 369-386.

Brown, A. E., \& Grant , G. G. (2005). Framing the frameworks: a review of IT governance research. Communication of the Association for Information Systems 15, 696-712.

Burlton, R. (2010). Delivering business strategy through process management. In J. Vom Brocke, and M. Rosemann (Eds), Handbook on Business Process Management 2 (pp. 5-73). Springer Berlin Heidelberg.

Corbin, J., \& Strauss, A. (2008). Basics of qualitative research (3rd ed.). Sage publications.

Davenport, T. (1993). Process Innovation: Reengineering Work through Information Technology. Harvard Business School Press.

Davis, R., \& Brabänder, E. (2007). ARIS design platform — getting started with BPM. Berlin Heidelberg New York: Springer.

De Bruin, T. (2009). Business process management: theory on progression and maturity. Queensland University of Technology.

De Haes, S., \& Van Grembergen, W. (2009). An exploratory study into IT governance implementations and its impact on business/IT alignment. Information Systems Management 26(2), 123-137. 
Doebeli, G., Fisher, R., Gapp, R., \& Sanzogni, L. (2011). Using BPM governance to align systems and practice. Business Process Management Journal 17(2), 184-202.

Feurer, R., Chaharbaghi, K., Weber, M., \& Wargin, J. (2000). Aligning strategies, processes, and IT: A case study. IEEE Engineering Management Review 28(3), 81-91.

Flyvbjerg, B. (2006). Five Misunderstandings about Case-Study Research, Qualitative Inquiry 12(2), 219-245

Blosch, M., \& Burton, B. (2015). Seven best practices for using enterprise architecture to power digital business. Gartner.

Fonstad, N. O., \& Robertson, D. (2006). Transforming a company, project by project: the IT engagement model. MIS Quarterly Executive 5(1), 1-14.

Hammer, M., \& Stanton, S. (1999). How Process Enterprises Really Work, Harvard Business Review. Retrieved from: www.hbr.org/1999/11/how-process-enterprises-really-work/ar/1, Accessed 09.02.15

Hammer, M. (2001). The process enterprise: an executive perspective. Hammer and Company, Retrieved from: www.hammerandco.com/pdf/process-enterprise-exec.pdf, Accessed 09.02.15.

Hammer, M. (2004). Natural business evolution may spawn a new executive role and changes for the CIO. Information Week, March.

Hammer, M., (2010). What is Business Process Management?. In J. Vom Brocke, and M. Rosemann (Eds.), Handbook on Business Process Management 1 (pp. 3-16). Springer Berlin Heidelberg. 
Harmon, P. (2008). Process Governance. BPTrends 6(3), Retrieved from:

http://www.sdn.sap.com/irj/scn/go/portal/prtroot/docs/library/uuid/10275f79-7243-2b10-2a99b576510b3864?QuickLink=index\&overridelayout=true\&31361851198678, Accessed 09.02.15

Harmon, P. (2010). The scope and evolution of business process management. In J. Vom Brocke, and M. Rosemann (Eds.), Handbook on Business Process Management 1 (pp. 38-81). Springer Berlin Heidelberg.

Henderson, J. C., \& Venkatraman, N. (1993). Strategic alignment: Leveraging information technology for transforming organizations. IBM systems journal 32(1), 4-16.

Holland, C. P., \& Light, B. (1999). A critical success factors model for ERP implementation. IEEE software 16(3), 30-36.

Hong, K. K., \& Kim, Y. G. (2002). The critical success factors for ERP implementation: an organizational fit perspective. Information \& Management 40(1), 25-40.

Hongjun, L., \& Nan, L. (2011). Process Improvement Model and Its Application for Manufacturing Industry Based on the BPM-ERP Integrated Framework. In Innovative Computing and Information (pp. 533-542). Springer Berlin Heidelberg.

Irani, Z. (2002). Information systems evaluation: navigating through the problem domain. Information \& management 40, 11-24.

ITGI. (2003). Board Briefing on IT Governance (2nd ed.). IT Governance Institute, Rolling Meadows, Illinois.

Kirchmer, M. (2011). Business Process Governance for MPE. In High Performance Through Process Excellence (pp. 69-85). Springer Berlin Heidelberg. 
Kooper, M. N., Maes, R., \& Lindgreen, E. R., (2011). On the governance of information: Introducing a new concept of governance to support the management of information. International Journal of Information Management 31 (3), 195-200.

Korhonen, J. (2007). On the lookout for organizational effectiveness-requisite control structure in BPM governance. In 1st International Workshop on BPM Governance.

Lee, J., Siau, K., \& Hong, S. (2003). Enterprise Integration with ERP and EAI. Communications of the ACM 46(2), 54-60.

Luftman, J. (1996). Competing in the Information Age: Practical Applications of the Strategic Alignment Model. Oxford University Press.

Luftman, J., \& Brier, T. (1999). Achieving and sustaining business-IT alignment. California management review 42(1), 109-122.

Markus, M. L., \& Jacobson, D. D. (2010). Business Process Governance. In J. Vom Brocke, and M. Rosemann, Handbook on Business Process Management 2 (pp. 201-222). Springer Berlin Heidelberg.

Masli, A., Richardson, V. J., Sanchez, J. M., \& Smith, R., E. (2011). The Business Value of IT: A Synthesis and Framework of Archival Research. Journal of Information Systems 25(2), 81-116.

Melenovsky, M. (2006). BPM Organizational Staffing and Structure. Gartner Research

Melville, N., Kraemer, K., \& Gurbaxani, V. (2004). Review: Information Technology and Organizational Performance: An integrative Model of IT Business Value. MIS Quarterly 28(2), 283-322. 
Niehaves, B., Plattfaut, R., \& Becker, J. (2012). Business process governance: a comparative study of Germany and Japan. Business Process Management Journal 18(2), 347-371.

Novotny, S., \& Rohmann, N. (2010). Toward a global process management system: The ThyssenKrupp Presta case. In J. Vom Brocke, and M. Rosemann, Handbook on Business Process Management 2 (pp. 355-367). Springer Berlin Heidelberg.

Orlikowski, W. (1992). The duality of technology. Organizational Science 3(3), 398-427.

Peppard, J., Ward, J., \& Daniel, E. (2007). Managing the realization of business benefits from IT investments. MIS Quarterly Executive 6(1), 1-11.

Peterson, R. (2004). Crafting information technology governance. Information Systems Management 21(4), 7-22.

Posthumus, S., Von Solms, R., \& King, M. (2010). The board and IT governance: The what, who and how. South African Journal of Business Management 41(3), 23-32.

Ranganathan, C. \& Kannabiran, G. (2004). Effective management of information systems function: an exploratory study of Indian organizations, International Journal of Information Management 24 (3), 247-266.

Rau, K. G. (2004). Effective governance of IT: Design objectives, roles, and relationships. Information Systems Management 21(4), 35-42.

Rosemann, M., \& Vom Brocke, J. (2010). The six core elements of business process management. In J. Vom Brocke, and M. Rosemann (Eds.), Handbook on Business Process Management 1 (pp. 107-122). Springer Berlin Heidelberg. 
Rosemann, M. (2010). The Service Portfolio of a BPM Center of Excellence. In J. Vom Brocke, and M. Rosemann (Eds.), Handbook on Business Process Management 1 (pp. 267-284). Springer Berlin Heidelberg.

Ross, J. W., \& Feeny, D. F. (1999). The evolving role of the CIO. Center for Information Systems Research, Sloan School of Management 308. Massachusetts Institute of Technology.

Santana, A. F. L., Alves, C. F., Santos, H. R. M., \& Felix, A. D. L. C. (2011). BPM Governance: An Exploratory Study in Public Organizations. In Enterprise, Business-Process and Information Systems Modeling (pp. 46-60). Springer Berlin Heidelberg.

Scheer, A. W., \& Brabänder, E. (2010). The process of business process management. In J. Vom Brocke, and M. Rosemann, Handbook on Business Process Management 2 (pp. 239-265). Springer Berlin Heidelberg.

Schwarz, A., Kalika, M., Kefi, H., \& Schwarz, C. (2010). A dynamic capabilities approach to understanding the impact of IT-enabled businesses processes and IT-business alignment on the strategic and operational performance of the firm. Communications of the Association for Information Systems 26(1), 57-84.

Scott, J. (1999). The FoxMeyer Drugs' bankruptcy: Was it a failure of ERP?. Americas Conference on Information Systems 80, 13-15.

Smith, H., \& Fingar, P. (2003). IT Doesn't Matter - Business Processes Do: A Critical Analysis of Nicholas Carr's I.T. Article in the Harvard Business Review, Meghan-Kiffer Press, Tampa, FL.

Spanyi, A. (2010). Business process management governance. In J. Vom Brocke, and M. Rosemann, Handbook on Business Process Management 2 (pp. 223-238). Springer Berlin Heidelberg. 
Spremić, M. A. R. I. O. (2009). IT governance mechanisms in managing IT business value. WSEAS Transactions on Information Science and Applications 6(6), 906-915.

Tallon, P. P., Kraemer, K. L., \& Gurbaxani, V. (2000). Executives' perceptions of the business value of information technology: a process-oriented approach. Journal of Management Information Systems, 145-173.

Tallon, P. P. (2007). A Process-Oriented Perspective on the Alignment of Information Technology and Business Strategy. Journal of Management Information Systems 24(3), 227-268.

Tarafdar, M., \& Gordon, S. R. (2007). Understanding the influence of information systems competencies on process innovation: A resource-based view. The Journal of Strategic Information Systems 16(4), 353-392.

Tarafdar, M., \& Qrunfleh, S. (2009). IT-business alignment: a two-level analysis. Information Systems Management 26(4): 338-349.

Teo, T. S., \& King, W. R. (1997). Integration between business planning and information systems planning: an evolutionary-contingency perspective. Journal of management information systems 14(1), 185-214.

Teo, T. S., \& Ang, J. S. K. (1999). Critical success factors in the alignment of IS plans with business plans. International Journal of Information Management 19(2), 173-185.

Teo, T. S., \& Ang, J. S. K. (2001). An examination of major IS planning problems. International Journal of Information Management 21 (6), 457-470.

Tracy, S. J. (2010). Qualitative quality: Eight “big-tent” criteria for excellent qualitative research. Qualitative inquiry 16(10), 837-851 
Tregear, R. (2009). Practical Governance. BPTrends, Retrieved from:

http://www.bptrends.com/publicationfiles/SEVEN\%2012-09-COL-Practical\%20Process-

Practical\%20Governance-Tregear\%20rt-final.pdf, Accessed 09.02.15

Trkman, P. (2010). The critical success factors of business process management. International Journal of Information Management 30(2), 125-134.

Tučková, Z., \& Tuček, D. (2011). Necessity of IT and SW support for business process management. International Journal of Mathematics and Computers in Simulation 5(1), 45-52.

Van Grembergen, W., De Haes, S., \& Guldentops, E. (2004). Structures, processes and relational mechanisms for IT governance. Strategies for information technology governance 2(004), 1-36.

Van Grembergen, W., \& De Haes, S. (2009). Enterprise Governance of Information Technology. Nova.

Wagner, H. T., Beimborn, D., \& Weitzel, T. (2014). How Social Capital Among Information Technology and Business Units Drives Operational Alignment and IT Business Value. Journal of Management Information Systems 31(1), 241-272.

Walsham, G. (1993). Interpreting information systems in organizations. New York: John Wiley \& Sons, Inc.

Weill, P., \& Ross, J. W. (2004). IT-Governance: How Top Performers Manage IT Decision Rights for Superior Results. Harvard Business Press.

Weill, P., \& Ross, J. W. (2009). IT Savvy: What top executives must know to go from pain to gain. Harvard Business Press. 
Weiss, J. W., Thorogood, A., \& Clark, K. D. (2006). Three IT-Business Alignment Profiles: Technical Resource, Business Enabler, and Strategic Weapon. Communications of the Association for Information Systems 18, 676-691.

Wilkin, C. L., \& Chenhall, R. H. (2010). A review of IT governance: A taxonomy to inform accounting information systems. Journal of Information Systems 24(2), 107-146.

Yin, R. K. (2009). Case study research: Design and methods, Sage Publications. 


\section{Figure Captions}

Figure 1: Methodology and contribution of paper

Figure 2: Process organization in Gamma

Figure 3: IS organization in Gamma

Figure 4: Integration between process governance structure and IS governance structure in

\section{Gamma}

Figure 5: First- and second-level concepts from data analysis and emergent integration properties explaining integration between BPM and IT management functions 


\section{Table Captions}

Table 1: Business process governance capabilities (De Bruin, 2009; Kirchmer, 2011; Santana, Alves, Santos \& Felix, 2011)

Table 2: IT governance capabilities (De Haes \& Van Grembergen, 2009; Peterson, 2004; Weill \& Ross, 2004)

Table 3: Number of papers on BPG and ITG topics found during structured literature search Table 4: Strategic and operational integration between BPM and IT management functions: the role of IT matters 